\title{
Marital Quality and Attachment: The Mediator Role of Conflict Resolution Styles ${ }^{1}$
}

\author{
Patrícia Scheeren \\ Universidade Federal do Rio Grande \\ do Sul, Porto Alegre-RS, Brazil \\ Viviane Ribeiro Goulart \\ Universidade Federal do Rio Grande \\ do Sul, Porto Alegre-RS, Brazil
}

\author{
Rebeca Veras de Andrade Vieira \\ Universidade Federal do Rio Grande \\ do Sul, Porto Alegre-RS, Brazil \\ Adriana Wagner ${ }^{2}$ \\ Universidade Federal do Rio Grande \\ do Sul, Porto Alegre-RS, Brazil
}

\begin{abstract}
Certain variables can act as mediators between marital quality, social and emotional aspects of the individuals and their context. The aim of this study was to investigate the role of conflict resolution styles as mediators between attachment styles and marital quality. A total of 214 couples participated in the present study aged between 18 and 75 years, residents in Southern Brazil. Three scales were administered: The Conflict Resolution Style Inventory, Golombok Rust Inventory of Marital State and Adult Attachment Scale. Results indicate that the styles of conflict resolution (positive problem solving, conflict engagement, withdrawal and compliance) mediate the relationship between attachment and marital quality. A difference between husbands and wives was observed. These findings suggest the importance of expanding the repertoire of positive strategies of conflict resolution of the couples for the promotion of marital quality.
\end{abstract}

Keywords: marital relations, marital conflict, attachment behavior

\section{Qualidade Conjugal e Apego: O Papel Mediador dos Estilos de Resolução de Conflito}

Resumo: Determinadas variáveis podem atuar como mediadoras entre a qualidade conjugal, os aspectos socioemocionais dos casais e seu contexto. O objetivo deste estudo foi testar se os estilos de resolução de conflitos atuam como mediadores da relação entre os estilos de apego e a qualidade conjugal. Participaram da pesquisa 214 casais, com idade entre 18 e 75 anos, residentes na região sul do Brasil. Foram utilizados quatro instrumentos: questionário sociodemográfico, The Conflict Resolution Style Inventory, Golombok Rust Inventory of Marital State e Escala de Apego Adulto. Os resultados apontaram que os estilos de resolução de conflitos (resolução positiva dos problemas, envolvimento no conflito, afastamento e submissão) mediaram a relação entre o apego e a qualidade conjugal, sendo observada uma diferença entre maridos e esposas. Esses achados sugerem a importância da ampliação do repertório de estratégias positivas de resolução de conflitos para o casal visando à promoção da qualidade conjugal.

Palavras-chave: relações conjugais, conflito conjugal, comportamento de apego

\section{Calidad Conyugal y Apego: El Papel del Mediador en los Estilos de Resolución de Conflicto}

\begin{abstract}
Resumen: Determinadas variables pueden actuar como mediadoras entre la calidad conyugal, los aspectos socioemocionales de las parejas y su contexto. El objetivo de este estudio fue verificar si los estilos de resolución de conflicto actúan como mediadores de la relación entre los estilos de apego y la calidad conyugal. Participaron de la investigación 214 parejas, entre 18 y 75 años, residentes en el sur de Brasil. Fueron utilizados cuatro instrumentos: The Conflict Resolution Style Inventory, Golombok Rust Inventory of Marital State y Escala de Apego Adulto. Los resultados mostraron que los estilos de resolución de conflictos (resolución positiva de los problemas, participación en el conflicto, eliminación y sumisión) mediaron la relación entre apego y calidad conyugal, observándose una diferencia entre maridos y esposas. Esos hallazgos sugieren la importancia de ampliación del repertorio de estrategias positivas de resolución de conflictos para las parejas visando a promover la calidad conyugal.
\end{abstract}

Palabras clave: relaciones conyugales, conflicto marital, conducta de apego

\footnotetext{
Support: FAPERGS/CNPq 008/2009 - PRONEX funding.

2 Correspondence address:

Adriana Wagner. Universidade Federal do Rio Grande do Sul, Instituto de Psicologia, Programa de Pós-Graduação em Psicologia. Rua Ramiro Barcelos, 2600, Santa Cecília. CEP 90035-003. Porto Alegre-RS, Brazil. E-mail: adrianawagner.ufrgs@hotmail.com
}

Several researchers have put tremendous effort into the no mean task of understanding what determines the quality of a marital relationship (Dixon, Gordon, Frousakis, \& Schumm, 2012; Fincham \& Beach, 2010; Pergher, 2010). Specific studies have therefore been conducted to evaluate the 
perception of the spouses on the quality of their relationship as a couple (Rust, Bennun, Crowe, \& Golombok, 1990, 2010). Marital quality refers to the degree of satisfaction, trust, respect and interest spouses share in their relationship (Falcke, 2003). The definition of this concept shows that it is multifactorial and thus, studies that incorporate variables of personal resources of the spouses, their adaptive processes and their context for understanding the phenomenon (Mosmann, Wagner, \& Féres-Carneiro, 2006; ScorsoliniComin \& Santos, 2009) are necessary.

Some studies have examined the relationship between quality of relationship between the members of a couple and marital conflict. Considering the context of interaction, marital conflict can be defined as any situation that involves both negative and positive difference of opinion (Cummings \& Davies, 2010). According to that definition, conflict is characterized as an event present in every marital relationship. Thus, one of the most relevant aspects for the evaluation of marital health is how couples resolve their conflicts. In the 1990s, Kurdek (1994) proposed four styles of resolving marital conflicts: positive problem solving, conflict engagement, withdrawal and compliance.

Spouses who have a positive problem solving style focus on the problem in question, discuss differences in a constructive manner, find acceptable alternatives for both partners, negotiate and compromise. Conflict engagement includes behaviors such as personal attacks, insults, bursting out and loss of control, in addition to attitudes such as getting carried away and saying things one does not really mean. In the withdrawal style, refusal to talk for long periods, refusal to continue a discussion, shutting down the other spouse and withdrawing, and acting in a distant and disinterested manner are predominant behaviors. Lastly, the compliance style involves behaviors of complacency, no defense of his or her position and quick giving up after a few attempts to try and present an opinion (Kurdek, 1994).

There is existing evidence that indicates that the manner in which spouses handle their conflicts influences their perception of marital quality (Askari, Noah, Hassan, \& Baba, 2012). International studies indicate a positive association between marital quality and positive strategies of conflict resolution, with higher levels of marital quality observed when spouses adopt targeted strategies to solve the conflict (Segrin, Hanzal, \& Domschke, 2009; Wheeler, Updegraff, \& Thayer, 2010). There is also evidence that destructive and/or competitive solving strategies are negatively associated with marital quality (McNulty \& Russell, 2010).

In addition to conflict management, the type of attachment in adults is also an important variable in the understanding of marital quality (Creasey, 2002; Marchand, 2004; Mohr, Selterman, \& Fassinger, 2013; Timm \& Keiley, 2011). Attachment is defined as the bond formed early in life between the individual and his primary caregiver (Bowlby, 1979), and has been described in three styles (secure, anxious-avoidant and anxious-ambivalent) based on
Ainsworth, Blehar, Waters and Wall's experiments (1978) with the mother-infant dyad.

Attachment theory assumes that the development of the bond occurs from internal working models (IWM) of the self and of the others. These childhood models take on prototypical functions for adult social relationships, guide expectations, perceptions and behaviors (Bowlby, 2004). Assuming that the IWM exert an influence on the development of intimate relationships, Hazan and Shaver (1987) initiated studies on attachment styles in adults. The authors believed that the quality of intimate relationships in adulthood was influenced by childhood events, particularly the relationship between the child and its caregiver. From that premise, they adapted the three types of attachment proposed by Ainsworth et al. (1978) for adult romantic relationships (Hazan \& Shaver, 1994).

Seeking to obtain greater methodological rigor, Collins and Read (1990) measured the three types of attachment described by Hazan and Shaver through an 18-item scale that measures dependence, closeness and anxiety. The dependency factor evaluates how much a person can trust others and depend on them. The anxiety factor reflects the fear of being abandoned or not loved. Closeness refers to how much a person feels comfortable being close and intimate with others. Although there is no direct relationship between the scales and the three attachment styles proposed by Ainsworth et al. (1978), discriminant analyses confirm they are equivalent.

Results by Collins and Read (1990) showed that attachment styles are related with the quality of communication, trust and satisfaction in couples. The data suggest that individuals comfortable with closeness tend to be more positive with relationships in general, more satisfied and close to their partner, they share more free time, perceive less conflict in the relationship, communicate better and tend to rely more on other. On the other hand, those with anxious attachment tend to evaluate their relationship in a negative way and they are less satisfied with their partner.

Studies show that people with secure attachment have higher levels of intimacy in relationships (Bartholomew \& Horowitz, 1991), favorable expectations in relation to their partner, better levels of marital quality (Collins \& Read, 1990), long-term and stable relationships (Hazan \& Shaver, 1987), and are optimistic about marriage in comparison to those with insecure attachment (Charania \& Ickes, 2007; Meyers \& Landsberger, 2002). Also, there is evidence that attachment styles are predictors of marital quality (Butzer \& Campbell, 2008; Knoke, Burau, \& Roehrle, 2010).

In addition to being associated with marital quality, attachment is also related to the strategies of conflict resolution to the extent that the IWM guide affections and specific behaviors during interactions with attachment figures (Bowlby, 1979). Studies on the relationship between attachment and marital conflict resolution strategies indicate that secure attachment is associated with positive communication strategies between husbands and wives (Salvatore, Kuo, Steele, Simpson, \& Collins, 2011). In the 
same line of investigation, Arricale's and Pistole's (2003) findings show that adults with secure attachment feel less threatened in discussions, use less conflict avoidance strategies and report a reduced frequency of conflicts and increased use of negotiation in comparison to those with insecure attachment. Furthermore, adults with secure attachment recognize that conflict can be beneficial to the relationship, as they consider that such situations help them to identify and solve differences, favoring marital intimacy.

In that context, Marchand (2004) investigated how attachment, depressive symptoms and conflict resolution behaviors influence marital quality. Results showed that women with insecure attachment were less susceptible to the positive problem solving than those with secure attachment. Moreover, frequency of conflict was greater in men with insecure attachment compared to those with secure attachment. In addition, conflict resolution had a mediator role between anxious attachment in women and marital quality without significant results for depressive symptoms.

These findings point to the need to investigate the relationship between conflict resolution styles, attachment styles and marital quality through a more refined model that considers the effect of context variables on variables related to social and emotional development in marital quality. In addition, Brazilian literature lacks evidence and models applicable to the local population. Therefore, the objective of this study was to test whether styles of conflict resolution act as relationship mediators between attachment styles and marital quality. In other words, in this study, the aim was to try to understand if the styles of conflict resolution attenuate or intensify the impact of attachment styles on marital quality. The mediation model investigated is shown in Figure 1.

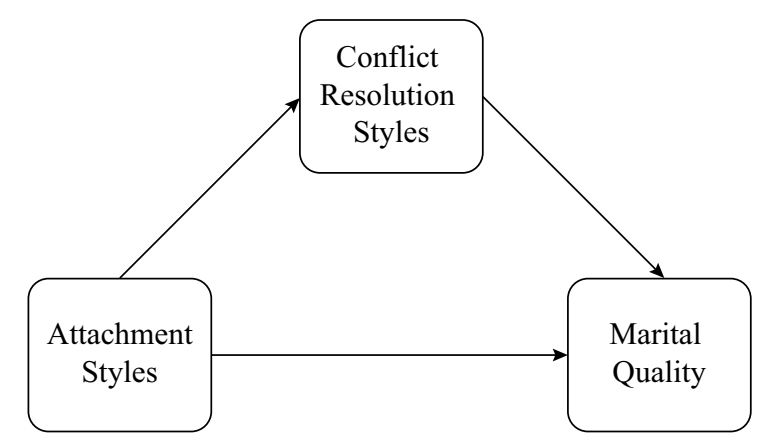

Figure 1. Mediator model (adapted from Marchand, 2004).

\section{Method}

\section{Participants}

A total of 214 heterosexual couples participated in this study, aged between 18 and 75 years, with a mean age of 40.18 years $(S D=10.76)$, from different social and economic backgrounds, who lived in 28 municipalities in the state of Rio Grande do Sul (Brazil). The sample consisted of $68 \%$ officially married couples and $31.3 \%$ couples who lived together or who characterized their relationship as a stable union. The average length of relationship with current spouse was of 14.91 years $(S D=9.87)$. Significant differences between husbands and wives were observed with respect to age $(t(426)=3.19, p=.01)$ and income $\left(X^{2}=54.86(4)\right.$, $p<.001)$. However, husbands and wives did not differ in relation to the degree of education $\left(X^{2}=11.64(8), p=.168\right)$. Social and demographic characteristics of the participants are shown in Table 1 .

Table 1

Social and Demographic Characteristics of the Sample

\begin{tabular}{lcc}
\hline Variables & Husbands & Wives \\
\hline Age & & \\
$\quad M(S D)$ & $41.84(10.68)$ & $38.55(10.62)$ \\
$\quad$ Amplitude & $20-70$ & $18-75$ \\
Education: $f(\%)$ & & \\
$\quad$ Primary and Middle School & $57(26.9)$ & $50(23.3)$ \\
High & $63(29.7)$ & $63(29.1)$ \\
Undergraduate & $57(26.9)$ & $46(21.3)$ \\
Graduate & $35(16.6)$ & $56(25.9)$ \\
Income (\# minimum wages): $f(\%)$ & & \\
No income & $2(0.9)$ & $37(17.1)$ \\
$1-3$ & $104(49.1)$ & $120(55.6)$ \\
$4-6$ & $44(20.8)$ & $35(16.2)$ \\
$7-9$ & $23(10.8)$ & $7(3.2)$ \\
10 or more & $37(17.5)$ & $12(5.6)$ \\
\hline
\end{tabular}

Note. $M=$ mean, $S D=$ standard deviation, $f=$ frequency, $\%=$ percentage.

\section{Instruments}

Social and Demographic Questionnaire is an instrument that was developed by the authors of this manuscript and was used to characterize the study sample in terms of age, education, income, marital status and length of relationship.

Golombok Rust Inventory of Marital State - GRIMS (Rust et al., 1990.) questionnaire was used to assess the quality of the marital relationship through dimensions considered important for a good relationship, such as satisfaction, communication, shared interests, trust and respect. The instrument has 28 items which the subject is expected to rate on a four-point Likert scale (with $1=$ strongly disagree to $4=$ strongly agree) according to his or her agreement. The total score is calculated by adding the scores of the 28 items. The higher the scores, the more severe the problems in the marital relationship. Cronbach's alpha coefficient obtained for GRIMS was.80 (Rust et al., 1990). The scale was translated and adapted by Falcke (2003) for the Brazilian population, obtaining a Cronbach's alpha value of.90. 
Conflict Resolution Style Inventory - CRSI (Kurdek, 1994) instrument was used to assess the solution patterns of marital conflicts, comprising four styles: positive problem solving, conflict engagement, withdrawal and compliance. Both spouses completed two sections of this instrument. The instrument has 16 items, measured on a five-point Likert scale (where $1=$ never and $5=$ always). Response values for each subscale are added resulting in the four scores that can vary from 4 to 20 . Cronbach's alpha values for the four subscales ranged from. 65 to. 89 . The scale was translated and adapted for this study sample of Brazilian adults, showing satisfactory internal consistency with Cronbach's alpha values in the subscales ranging from.53 to. 77 .

Adult Attachment Scale - AAS (Collins \& Read, 1990) is a scale used to evaluate three types of attachment: closeness, trust and anxiety through the scoring of 18 items on a five-point Likert scale (where $1=$ has nothing to do with $m e$ and $5=$ has a lot to do with $\mathrm{me}$ ). In the original version, Cronbach's alpha values for the three subscales ranged between .63 and .83. The Brazilian version, adapted by Silva (2008), showed three dimensions consistent with the dimensions of the original scale, with a Cronbach's alpha of.84. In this study, exploratory factor analysis showed four factors defined as anxiety, comfort with closeness, difficulty in trusting and discomfort with closeness. Cronbach's alpha values ranged from .57 to .77 .

\section{Procedure}

Data collection. Participants were approached using criteria of convenience and by means of contact with schools, community centers, churches and also from referrals made by the study subjects. Data collection occurred between August 2010 and December 2011 in the homes of the participants following appointments made over the telephone. Participants were instructed to complete all the scales, bearing in mind their marital relationship. The scales were administered to each spouse separately and simultaneously and there was no communication between them. Scales were administered following their order of presentation in the Instruments section of this article. Data collection was preceded by completion of an Informed Consent Form by all the participants.

Data analysis. Pearson Correlation Analysis and Multiple Linear Regression were used to test the mediation model. The methods of Baron and Kenny (1986) were used to investigate the extent to which conflict resolution strategies mediated the relationship between adult attachment and marital quality. According to those authors, three conditions need to be satisfied to confirm the mediation model: (a) the independent variable (adult attachment style) must be significantly related to the mediator variable (conflict resolution strategies), (b) the mediating variable must be significantly related to the dependent variable (marital quality), and (c) the addition of the mediator variable should weaken the relationship between the independent and dependent variables. It is important to highlight that the relationship between the dependent and independent variables, when regressed with the mediator, may not be significant (full mediation) or may simply lower beta value and remain significant (partial mediation). To confirm mediation, Sobel's Test was carried out in order to measure the indirect effect of the independent variable on the dependent variable through the mediator. Missing data were treated by assigning a variable average.

\section{Ethical Considerations}

This study was conducted according to the guidelines proposed by the Brazilian legislation based on National Health Council Resolution 196/96, effective at the time of data collection, and on Resolution 16/2000 of the Federal Council of Psychology. This study received approval from the Ethics Committee of the UFRGS in October 2009 (Protocol 2009/ 040).

\section{Results}

\section{Correlation Analyses}

Table 2 shows the correlation matrix in wives and in husbands for the investigated variables including social and demographic variables. Results for the husbands indicate that marital quality was significantly correlated with all the attachment styles and all the styles of conflict resolution. The attachment style "discomfort with closeness" correlated with all the styles of conflict resolution, while the "difficulty in trusting" style did not correlate with any style of conflict resolution. With respect to the attachment style "anxiety" it was associated with all the styles of conflict resolution, except for "positive problem solving". However, "positive problem solving" was the only style to correlate with "comfort with closeness". Resolution style "compliance" was positively associated with age and length of relationship but negatively associated with education. As for the resolution style "withdrawal from conflict", it was positively associated with education and income. The attachment style "anxiety" was negatively associated with income. Finally, marital quality was negatively associated with length of relationship.

All the attachment styles correlated with the styles of conflict resolution for the wives, except for the attachment style "comfort with closeness" and the resolution styles "conflict engagement" and "withdrawal from conflict". As with the husbands, marital quality was correlated with all styles of conflict resolution and attachment. And still in the same group, marital quality was negatively associated with education and income. It is important to note that the lower the scores on GRIMS scale the higher the level of marital quality. "Compliance" style was positively correlated with age and length of relationship, however, negatively correlated with education and income. Also, the "conflict engagement" style 
was negatively correlated with the length of relationship and the "positive problem solving" style and positively correlated with the education variable. The attachment style "anxiety" was negatively related with the length of relationship, education and income. The "difficulty in trusting" style was negatively related with education. Finally, the "discomfort with closeness" style was positively associated with age and negatively associated with education and income.

Table 2

Bivariate Correlations Among Investigated Study Variables

\begin{tabular}{|c|c|c|c|c|c|c|c|c|c|c|c|c|c|}
\hline \multirow[b]{2}{*}{ Variable } & \multirow[b]{2}{*}{1} & \multirow[b]{2}{*}{2} & \multicolumn{8}{|c|}{ Sample Husbands/Wives ${ }^{\text {a }}$} & \multirow[b]{2}{*}{11} & \multirow[b]{2}{*}{12} & \multirow[b]{2}{*}{13} \\
\hline & & & 3 & 4 & 5 & 6 & 7 & 8 & 9 & 10 & & & \\
\hline 1-Age & - & $.81 * *$ & -.06 & $.24 * *$ & -.05 & .04 & -.05 & .03 & $.16^{*}$ & -.01 & .01 & -.07 & .02 \\
\hline 2- TR & $.82 * *$ & - & -.12 & $.17 *$ & $-.14^{*}$ & .01 & -.07 & .01 & $.20 *$ & -.03 & .02 & -.00 & .08 \\
\hline 3- Education & $-.19 *$ & $-.23 * *$ & - & $.58 * *$ & -.06 & .07 & -.05 & $.15^{*}$ & $-.25 * *$ & -.09 & .10 & -.08 & -.13 \\
\hline 4- Income & .08 & -.01 & $.53 * *$ & - & -.09 & .03 & -.03 & $.19 *$ & -.09 & $-.19 *$ & -.09 & -.11 & -.10 \\
\hline 5- GRIMS & .11 & .03 & $-.23 * *$ & -.06 & - & $.44 * *$ & $-.42 * *$ & $.28 * *$ & $.16^{*}$ & $.27 * *$ & $-.20 *$ & $.17 *$ & $.25^{* *}$ \\
\hline 6-CRSI_1 & -.05 & $-.13 *$ & -.05 & .04 & $.49 * *$ & - & $-.35^{* *}$ & $.40 * *$ & .07 & $.19 *$ & -.06 & .09 & $.17 *$ \\
\hline 7-CRSI_2 & -.00 & .02 & $.15^{*}$ & .01 & $-.50 * *$ & $-.49 * *$ & - & $-.22 *$ & -.04 & -.09 & $.25^{* *}$ & -.02 & $-.14 *$ \\
\hline 8-CRSI_3 & .02 & -.02 & -.10 & .08 & $.31 * *$ & $.19^{* *}$ & $-.28 * *$ & - & $.27 * *$ & $.16^{*}$ & -.02 & .06 & $.14^{*}$ \\
\hline 9-CRSI_4 & $.15^{*}$ & $.13^{*}$ & $-.31 * *$ & $-.16^{*}$ & $.33 * *$ & .11 & $-.21^{*}$ & $.23^{* *}$ & - & $.14 *$ & -.03 & .03 & $.25 * *$ \\
\hline 10-Attachment_1 & -.10 & $-.13 *$ & $-.21 *$ & $-.18^{*}$ & $.41 * *$ & $.37 * *$ & $.31 * *$ & $.20 *$ & $.22 *$ & - & .08 & $.33 * *$ & $.51^{* *}$ \\
\hline 11-Attachment_2 & -.02 & -.03 & -.12 & -.05 & $-.28 * *$ & .02 & $.24 * *$ & -.05 & $-.17 *$ & .05 & - & -.03 & .04 \\
\hline 12-Attachment_3 & .05 & -.01 & $-.21 *$ & -.09 & $.30 * *$ & $.19 *$ & $-.14^{*}$ & $.13 *$ & $.14 *$ & $.48 * *$ & -.13 & - & $.35 * *$ \\
\hline 13-Attachment_4 & $.14^{*}$ & .04 & $-.28 * *$ & $-.14 *$ & $.30 * *$ & $.29 * *$ & $-.25 * *$ & $.18^{*}$ & $.21 *$ & $.49 * *$ & -.02 & $.41 * *$ & - \\
\hline
\end{tabular}

Note. TR = time of relationship, GRIMS = marital quality, CRSI 1 = conflict engagement subscale, CRSI 2 = positive problem solving subscale, CRSI_3 = withdrawal,CRSI_4= compliance, attachment_1= anxiety, attachment_2=comfort with closeness, attachment_3=difficulty in trusting, attachment 4 = discomfort with closeness.

aLower diagonal relates to the group of wives while the upper diagonal represents husbands' correlations.

$* p<.05 . * * p<.01$.

\section{Mediation Analysis}

Tables 3 and 4 show the Multiple Linear Regression analyses used in the mediation models investigated in wives and husbands, respectively. Only those results that met the three criteria described by Baron and Kenny (1986) for the mediation model are presented. All the analyses had $\mathrm{Z}$ values greater than $+/-1.46$ and $p<.05$ in Sobel's Test. Analysis of the mediator role was performed separately in husbands and wives. Results for the husbands showed five significant mediator models. As for the wives, 14 significant models were found. In the husbands group, the relationship between anxious attachment style and marital quality was mediated by the "conflict engagement" and "withdrawal" styles. As for the "comfort with closeness" style it was only mediated by "positive conflict resolution". Lastly, the attachment style "discomfort with closeness" was mediated by both "conflict engagement" and "positive conflict resolution".

One might think that, in husbands, marital quality is influenced by an insecure attachment style associated with a negative conflict resolution. On the other hand, secure attachment associated with positive solving of the conflict also had an effect on marital quality, decreasing the scores in the GRIMS scale, which indicates an increase in marital quality. Moreover, the specific type of attachment "discomfort with closeness" was mediated by both a negative and positive style of conflict resolution, where the negative conflict resolution style increases GRIMS scores $(\beta=1.23)$, suggesting a decrease in marital quality, while the positive problem solving style decreases GRIMS scores $(\beta=-0.94)$, indicating an increase in marital quality. In the wives group, the "anxious", "difficulty in trusting" and "discomfort with closeness" attachment styles were mediated by all styles of conflict resolution. However, the attachment style "comfort with closeness" was only mediated by the "positive problem solving" and "compliance" styles.

Results indicate that the "anxiety" attachment style increases GRIMS scores $(\beta=0.80)$, however, the ratio decreases $(\beta=0.55)$ when mediated by the positive style of conflict resolution. Furthermore, positive conflict resolution decreases GRIMS score $(\beta=-1.23)$, which indicates an increase in marital quality. And the "comfort with closeness" attachment style decreases GRIMS scores $(\beta=-0.70)$ and that ratio boosted $(\beta=-0.42)$ when mediated by positive conflict resolution. Therefore, positive problem solving decreases GRIMS score $(\beta=-1.38)$ and improves marital quality. The same occurs with "difficulty in trusting" attachment style, it increases GRIMS scores $(\beta=1.11)$, however, the ratio decreases $(\beta=0.86)$ when mediated by the positive conflict resolution style. Thus, positive problem solving decreases GRIMS score $(\beta=-1.40)$, which indicates an increase in marital quality. With respect to the "discomfort with closeness" attachment style it increases the scores of marital quality ( $\beta=1.11$ ), however, the ratio 
decreases $(\beta=0.68)$ when mediated by the positive conflict resolution style. Moreover, the positive problem solving style decreases GRIMS score $(\beta=-1.35)$, showing an improvement in marital quality.

Table 3

Multiple Linear Regression Analysis to Test the Mediator Effect of Conflict Resolution Strategies for Marital Quality in Husbands

\begin{tabular}{|c|c|c|c|c|c|c|c|}
\hline \multirow{2}{*}{$\begin{array}{l}\text { Dependent } \\
\text { Variable }\end{array}$} & \multirow{2}{*}{ Equation Variables } & \multirow{2}{*}{$R^{2}$} & \multirow{2}{*}{$\beta^{*}$} & \multirow{2}{*}{$t$} & \multirow{2}{*}{$p$-value } & \multicolumn{2}{|c|}{ Sobel's Test } \\
\hline & & & & & & $Z$ & $p$-value \\
\hline crsi_1 & Attachment_1 & .03 & 0.11 & 2.87 & .00 & 2.64 & .00 \\
\hline Grims & Attachment_1 & .07 & 0.48 & 4.15 & .00 & & \\
\hline \multirow[t]{2}{*}{ Grims } & Attachment_1 & .23 & 0.34 & 3.19 & .00 & & \\
\hline & crsi_1 & & 1.21 & 6.53 & .00 & & \\
\hline crsi_3 & Attachment_1 & .02 & 0.07 & 2.37 & .01 & 1.97 & .04 \\
\hline Grims & Attachment_1 & .07 & 0.48 & 4.15 & .00 & & \\
\hline \multirow[t]{2}{*}{ Grims } & Attachment_1 & .13 & 0.41 & 3.62 & .00 & & \\
\hline & crsi_3 & & 0.89 & 3.73 & .00 & & \\
\hline crsi_2 & Attachment_2 & .06 & 0.22 & 3.89 & .00 & -3.28 & .00 \\
\hline Grims & Attachment_2 & .04 & -0.41 & -3.06 & .00 & & \\
\hline \multirow[t]{2}{*}{ Grims } & Attachment_2 & .19 & -0.20 & -1.60 & .11 & & \\
\hline & crsi_2 & & -0.95 & -6.20 & .00 & & \\
\hline crsi_1 & Attachment_4 & .03 & 0.15 & 2.54 & .01 & 2.36 & .01 \\
\hline Grims & Attachment_4 & .06 & 0.70 & 3.85 & .00 & & \\
\hline \multirow[t]{2}{*}{ Grims } & Attachment_4 & .22 & 0.50 & 3.02 & .00 & & \\
\hline & crsi_1 & & 1.23 & 6.64 & .00 & & \\
\hline crsi_2 & Attachment_4 & .02 & -0.16 & -2.09 & .03 & 1.98 & .04 \\
\hline Grims & Attachment_4 & .06 & 0.70 & 3.85 & .00 & & \\
\hline \multirow[t]{2}{*}{ Grims } & Attachment_4 & .22 & 0.54 & 3.24 & .00 & & \\
\hline & crsi_2 & & -0.94 & -6.45 & .00 & & \\
\hline
\end{tabular}

Note. CRSI $1=$ conflict engagement subscale, CRSI $2=$ positive problem solving subscale, crsi $3=$ withdrawal, CRSI $4=$ compliance, attachment $1 \overline{1}=$ anxiety, attachment $2=$ comfort and closeness, attachment $3=$ difficulty in trusting, attachment_4= discomfort with closeness. *Non-standardized coefficient.

Most of the variances explained in the regression equations were significant, however, they displayed a low percentage. Nonetheless, an increase was observed in the variance explained of all the equations, which in turn supports that the inclusion of a mediator variable represents progress in the understanding of the marital quality.

\section{Discussion}

The main objective of this study was to test whether the styles of conflict resolution act as mediators of the relationship between attachment styles and marital quality. The results taken from the correlation matrix indicated that marital quality was significantly associated with all attachment styles and all conflict resolution styles for both in husbands and in wives. Thus, this study has shown evidence which supports findings of previous studies, despite the authors not necessarily having used the same measuring instruments to investigate such associations (Creasey, 2002; Marchand, 2004; Mohr et al., 2013; . Timm \& Keiley, 2011).

In this study, moderate correlations between variables are emphasized. In husbands and wives, the "conflict engagement" style was associated with poorer marital quality $(r=.49$ for women, $r=.44$ for men). In other words, results suggest that behaviors such as personal attacks, insults and loss of control during a marital conflict (Kurdek, 1994) are related to lower levels of marital quality. Likewise, couples who focus on the problem, constructively discuss differences and establish agreements show better marital quality $(r=-.50$ for women, $r=-.42$ for men). In women, an anxious attachment type was associated with poorer marital quality $(r=.41)$.

The large number of bivariate correlations among the variables investigated in this study is probably due to the high frequency of inter-relationship among variables in the humanities, as this is a study of complex phenomena. Moreover, the partial mediator model tested accepts the fact that, as most areas in psychology investigate multi-causal phenomena, a more realistic goal would be to seek mediators that lessened the strength of the relationship between attachment and marital quality rather than eliminate it altogether, since it was found relevant (Baron \& Kenny, 1986).

The mediation model was tested using the criteria proposed by Baron and Kenny (1986). Results indicate that the styles of conflict resolution act as mediators of the relationship among attachment styles and marital quality. 
Scheeren, P., Vieira, R. V. A., Goulart, V. R., \& Wagner, A. (2014). Marital Quality, Attachment and Conflict.

Table 4

Multiple Linear Regression Analysis to Test the Mediator Effect of Conflict Resolution Strategies for Marital Quality in Wives

\begin{tabular}{|c|c|c|c|c|c|c|c|}
\hline \multirow{2}{*}{$\begin{array}{l}\text { Dependent } \\
\text { Variable }\end{array}$} & \multirow{2}{*}{ Equation Variables } & \multirow{2}{*}{$R^{2}$} & \multirow{2}{*}{$\beta^{*}$} & \multirow{2}{*}{$t$} & \multirow{2}{*}{$p$-value } & \multicolumn{2}{|c|}{ Sobel's Test } \\
\hline & & & & & & $\mathrm{Z}$ & $p$-value \\
\hline crsi_1 & attachment_1 & .13 & 0.26 & 5.83 & .00 & 4.30 & .00 \\
\hline grims & attachment_1 & .17 & 0.80 & 6.63 & .00 & & \\
\hline \multirow[t]{2}{*}{ grims } & attachment_1 & .30 & 0.52 & 4.34 & .00 & & \\
\hline & crsi_1 & & 1.09 & 6.40 & .00 & & \\
\hline crsi_2 & attachment_1 & .09 & -0.20 & -4.80 & .00 & 3.96 & .00 \\
\hline grims & attachment_1 & .17 & 0.80 & 6.63 & .00 & & \\
\hline \multirow[t]{2}{*}{ grims } & attachment_1 & .32 & 0.55 & 4.78 & .00 & & \\
\hline & crsi_2 & & -1.23 & -7.05 & .00 & & \\
\hline crsi_3 & attachment_1 & .04 & 0.08 & 3.03 & .00 & 2.42 & .01 \\
\hline grims & attachment_1 & .17 & 0.80 & 6.63 & .00 & & \\
\hline \multirow[t]{2}{*}{ grims } & attachment_1 & .22 & 0.71 & 5.91 & .00 & & \\
\hline & crsi_3 & & 1.21 & 3.96 & .00 & & \\
\hline crsi_4 & attachment_1 & .04 & 0.09 & 3.33 & .00 & 2.60 & .00 \\
\hline grims & attachment_1 & .17 & 0.80 & 6.63 & .00 & & \\
\hline \multirow[t]{2}{*}{ grims } & attachment_1 & .23 & 0.69 & 5.79 & .00 & & \\
\hline & crsi_4 & & 1.12 & 4.09 & .00 & & \\
\hline crsi_2 & attachment_2 & .05 & 0.20 & 3.64 & .00 & -3.27 & .00 \\
\hline grims & attachment_2 & .07 & -0.70 & -4.25 & .00 & & \\
\hline \multirow[t]{2}{*}{ grims } & attachment_2 & .28 & -0.42 & -2.78 & .00 & & \\
\hline & crsi_2 & & -1.38 & -7.78 & .00 & & \\
\hline crsi_4 & attachment_2 & .03 & -0.09 & -2.58 & .01 & -2.26 & .02 \\
\hline grims & attachment_2 & .07 & -0.70 & -4.25 & .00 & & \\
\hline \multirow[t]{2}{*}{ grims } & attachment_2 & .16 & -0.57 & -3.58 & .00 & & \\
\hline & crsi_4 & & 1.28 & 4.54 & .00 & & \\
\hline crsi_1 & attachment_3 & .03 & 0.25 & 2.90 & .00 & 2.70 & .00 \\
\hline grims & attachment_3 & .09 & 1.11 & 4.65 & .00 & & \\
\hline \multirow[t]{2}{*}{ grims } & attachment_3 & .28 & 0.79 & 3.65 & .00 & & \\
\hline & crsi_1 & & 1.24 & 7.61 & .00 & & \\
\hline crsi_2 & attachment_3 & .02 & -0.18 & -2.16 & .03 & 2.09 & .03 \\
\hline grims & attachment_3 & .09 & 1.11 & 4.65 & .00 & & \\
\hline \multirow[t]{2}{*}{ grims } & attachment_3 & .31 & 0.86 & 4.06 & .00 & & \\
\hline & crsi_2 & & -1.40 & -8.19 & .00 & & \\
\hline crsi_3 & attachment_3 & .01 & 0.10 & 2.00 & .04 & 1,82 & .06 \\
\hline grims & attachment_3 & .09 & 1,11 & 4.65 & .00 & & \\
\hline \multirow[t]{2}{*}{ grims } & attachment_3 & .16 & 0,97 & 4.20 & .00 & & \\
\hline & crsi_3 & & 1,39 & 4.43 & .00 & & \\
\hline crsi_4 & attachment_3 & .02 & 0.11 & 2.12 & .03 & 1.93 & .05 \\
\hline grims & attachment_3 & .09 & 1.11 & 4.65 & .00 & & \\
\hline \multirow[t]{2}{*}{ grims } & attachment_3 & .17 & 0.96 & 4.15 & .00 & & \\
\hline & crsi_4 & & 1.29 & 4.65 & .00 & & \\
\hline crsi_1 & attachment_4 & .08 & 0.38 & 4.53 & .00 & 3.85 & .00 \\
\hline grims & attachment_4 & .09 & 1.11 & 4.72 & .00 & & \\
\hline \multirow[t]{2}{*}{ grims } & attachment_4 & .27 & 0.64 & 2.89 & .00 & & \\
\hline & crsi_1 & & 1.22 & 7.19 & .00 & & \\
\hline crsi_2 & attachment_4 & .06 & -0.31 & -3.92 & .00 & 3.48 & .00 \\
\hline grims & attachment_4 & .09 & 1.11 & 4.72 & .00 & & \\
\hline \multirow[t]{2}{*}{ grims } & attachment_4 & .28 & 0.68 & 3.16 & .00 & & \\
\hline & crsi_2 & & -1.35 & -7.62 & .00 & & \\
\hline
\end{tabular}

Continue 


\begin{tabular}{|c|c|c|c|c|c|c|c|}
\hline \multicolumn{8}{|c|}{ Continuation } \\
\hline crsi_3 & attachment_4 & .03 & 0.13 & 2.72 & .00 & 2.29 & .02 \\
\hline grims & attachment_4 & .09 & 1.11 & 4.72 & .00 & & \\
\hline \multirow[t]{2}{*}{ grims } & attachment_4 & .16 & 0.93 & 4.05 & .00 & & \\
\hline & crsi_3 & & 1.34 & 4.24 & .00 & & \\
\hline crsi_4 & attachment_4 & .04 & 0.17 & 3.22 & .00 & 2.57 & .00 \\
\hline grims & attachment_4 & .09 & 1.11 & 4.72 & .00 & & \\
\hline \multirow[t]{2}{*}{ grims } & attachment_4 & .16 & 0.89 & 3.87 & .00 & & \\
\hline & crsi_4 & & 1.23 & 4.35 & .00 & & \\
\hline
\end{tabular}

Note. CRSI_1 = conflict engagement subscale, CRSI_ $2=$ positive problem solving subscale, CRSI_ $3=$ withdrawal, CRSI $4=$ compliance, attachment $\overline{1}=$ anxiety, attachment $2=$ comfort and closeness, attachment $3=$ difficulty in trusting, attachment $4=$ discomfort with closeness. *Non-standardized coefficient.

The mediator model showed differences between husbands and wives indicating idiosyncrasies in responses.

Additionally, the analyses also allowed us to learn about the direction of the effects of attachment styles and conflict resolution strategies on marital quality. Which is to say, inclusion of the mediating variable in the model increases or decreases marital quality in each of the combinations of attachment styles and conflict resolution styles. Overall, insecure attachment (anxious attachment, discomfort with closeness and difficulty in trusting) associated with a style of negative conflict resolution (conflict engagement, withdrawal and compliance) decreases levels of marital quality. On the other hand, a secure type of attachment (comfort with closeness) associated with positive conflict resolution tends to improve marital quality.

For both men and women, however, it was noted that marital quality tends to increase when positive conflict resolution is used, even when anxious attachment, discomfort with closeness and difficulty in trusting styles are present. Conversely, in women, marital quality is impaired by the compliance style of conflict resolution, even when they have the attachment style of comfort with closeness.

Thus, the results indicate that, when marital quality is assessed, the type of attachment between the couple and characteristics of marital conflict should be considered, and the clinical research should value how the couple resolves its conflicts. This result highlights the importance of interventions focusing on marital communication and the development of empathy by the couple, to promote improvement of positive strategies of conflict resolution (Dattilio, 2010), which can reduce the negative impact of attachment styles on marital quality. It can be considered that, although a negative attachment style represents a predictor of poor marital quality, the use of positive problem solving represents a protective factor for couple's relationship. The mediation analyses provided relevant information about the different ways in which attachment styles affect marital quality. In this view, it was observed that the styles of conflict resolution appear as predictors of the relationship between attachment and marital quality.

The differences between men and women may be due to the fact that only self-report measures were used and that other factors specific to the cognitive functioning of men and women were disregarded. The literature suggests that husbands and wives may have different perceptions and behaviors related to styles of conflict resolution in their relationship (Hoppmann \& Blanchard-Fields, 2011; Marchand, 2004). Moreover, husbands and wives may assess their marital quality differently such as husbands tend to assess relationships more positively than their wives (Falcke, Wagner, \& Mosmann, 2008). However, further studies are needed to improve the understanding of this phenomenon.

\section{Final Considerations}

This study has contributed to investigate the reverberation of the different dimensions of attachment and conflict resolution in marital quality. Thus, it was possible to test a mediator model between those variables that proved valid to expand the understanding of this complex phenomenon.

Some study limitations can be pointed out. The study data were composed of self-reported measures only and, therefore, some variance may be related to the way the participants reported the data. Moreover, although couples responded to the same questionnaires data were not treated as dyad and it was not considered that men and women may have different perceptions on the issues of the conflicts measured in the questionnaires. As proposed by Kenny and Lendermann (2010), to treat data as a dyad is to perceive them as interdependent, that is, the influence of causality on the results of that person as well as of the partner are considered. In future research, we recommend using the APIM (The Actor-Partner Interdependence Model) method to treat data as dyads. Moreover, as the data come from a cross-sectional study, they cannot be understood as cause and effect (Marchand, 2004). Thus, longitudinal studies are suggested to investigate the influence of these variables throughout marital development.

In terms of contribution, these findings are of great value for clinical practice in that they show the advantages of clinical work to enhance the repertoire of strategies for positive problem solving of conflicts in couples, as they constitute protection factors against the impact of 
insecure attachment in marital quality. It is important that professionals who work with couples are aware of the type of attachment a couple has and that they intervene in the expansion of this repertoire with the objective of promoting better levels of marital quality.

\section{References}

Ainsworth, M. D. S., Blehar, M. C., Waters, E., \& Wall, S. (1978). Patterns of attachment: A psychological study of the strange situation. Hillsdale, NJ: Lawrence Erlbaum.

Askari, M., Noah, S. B. M., Hassan, S. A. B., \& Baba, M. B. (2012). Comparison the effects of communication and conflict resolution skills training on marital satisfaction. International Journal of Psychological Studies, 4(1), 182-195. doi:10.5539/ijps.v4n1p182

Baron, R. M., \& Kenny, D. A. (1986). The moderator-mediator variable distinction in social psychological research: Conceptual, strategic, and statistical considerations. Journal of Personality and Social Psychology, 51(6), 1173-1182. doi:10.1037/0022-3514.51.6.1173

Bartholomew, K., \& Horowitz, L. M. (1991). Attachment styles among young adults: A test of a four-category model. Journal of Personality and Social Psychology, 61(2), 226-244. doi:10.1037/0022-3514.61.2.226

Bowlby, J. (1979). The making \& breaking of affectional bonds. London, England: Tavistock.

Bowlby, J. (2004). Apego e perda: Vol. 3. Perda: Tristeza e depressão (V. Dutra, Trad., 3rd ed.). São Paulo, SP: Martins Fontes.

Butzer, B., \& Campbell, L. (2008). Adult attachment, sexual satisfaction, and relationship satisfaction: A study of married couples. Personal Relationships, 15(1), 141-154. doi:10.1111/j.1475-6811.2007.00189.x

Charania, M. R., \& Ickes, W. (2007). Predicting marital satisfaction: Social absorption and individuation versus attachmentanxietyandavoidance.PersonalRelationships, 14(2), 187-208. doi:10.1111/j.1475-6811.2007.00150.x

Collins, N. L., \& Read, S. J. (1990). Adult attachment, working models, and relationship quality in dating couples. Journal of Personality and Social Psychology, 58(4), 644-663. doi:10.1037/0022-3514.58.4.644

Creasey, G. (2002). Associations between working models of attachment and conflict management behavior in romantic couples. Journal of Counseling Psychology, 49(3), 365-375. doi:10.1037/0022-0167.49.3.365

Cummings, E. M., \& Davies, P. T. (2010). Marital conflict and children: An emotional security perspective. New York, NY: Guilford.

Dattilio, F. M. (2010). Cognitive-behavioral therapy with couples and families: A comprehensive guide for clinicians. New York, NY: Guilford.
Dixon, L. J., Gordon, K. C., Frousakis, N. N., \& Schumm, J. A. (2012). A study of expectations and the marital quality of participants of a marital enrichment seminar. Family Relations, 61(1), 75-89. doi:10.1111/j.1741-3729.2011.00681.x

Falcke, D. (2003). Águas passadas não movem moinhos? As experiências na família de origem como preditoras da qualidade do relacionamento conjugal (Unpublished doctoral dissertation). Pontifícia Universidade Católica do Rio Grande do Sul, Porto Alegre, RS.

Falcke, D., Wagner, A., \& Mosmann, C. P. (2008). The relationship between family-of-origin and marital adjustment for couples in Brazil. Journal of Family Psychotherapy, 19(2), 170-186. doi:10.1080/08975350801905020

Fincham, F. D., \& Beach, S. R. H. (2010). Marriage in the new millennium: A decade in review. Journal of Marriage and Family, 72(3), 630-649. doi:10.1111/j.1741-3737.2010.00722.x

Hazan, C., \& Shaver, P. (1987). Romantic love conceptualized as an attachment process. Journal of Personality and Social Psychology, 52(3), 511-524. doi:10.1037/0022-3514.52.3.511

Hazan, C., \& Shaver, P. R. (1994). Attachment as an organizational framework for research on close relationships. Psychological Inquiry, 5(1), 1-22. doi:10.1207/s15327965pli0501_1

Hoppmann, C. A., \& Blanchard-Fields, F. (2011). Problemsolving variability in older spouses: How is it linked to problem-, person-, and couple-characteristics? Psychology and Aging, 26(3), 525-531. doi:10.1037/a0024114

Kenny, D. A., \& Ledermann, T. (2010). Detecting, measuring, and testing dyadic patterns in the actor-partner interdependence model. Journal of Family Psychology, 24(3), 359-366. doi:10.1037/a0019651

Knoke, J., Burau, J., \& Roehrle, B. (2010). Attachment styles, loneliness, quality, and stability of marital relationships. Journal of Divorce \& Remarriage, 51(5), 310-325. doi:10.1080/10502551003652017

Kurdek, L. A. (1994). Conflict resolution styles in gay, lesbian, heterosexual nonparent, and heterosexual parent couples. Journal of Marriage and the Family, 56(3), 705-722. doi:10.2307/352880

Marchand, J. F. (2004). Husbands' and wives' marital quality: The role of adult attachment orientations, depressive symptoms, and conflict resolution behaviors. Attachment \& Human Development, 6(1), 99-112. doi:10.1080/14616730310001659575

McNulty, J. K., \& Russell, V. M. (2010). When "negative" behaviors are positive: A contextual analysis of the longterm effects of problem-solving behaviors on changes in relationship satisfaction. Journal of Personality and Social Psychology, 98(4), 587-604. doi:10.1037/a0017479. 
Meyers, S. A., \& Landsberger, S. A. (2002). Direct and indirect pathways between adult attachment style and marital satisfaction. Personal Relationships, 9(2), 159-172. doi:10.1111/1475-6811.00010

Mohr, J. J., Selterman, D., \& Fassinger, R. E. (2013). Romantic attachment and relationship functioning in same-sex couples. Journal of Counseling Psychology, 60(1), 72-82. doi:10.1037/a0030994

Mosmann, C., Wagner, A., \& Féres-Carneiro, T. (2006). Qualidade conjugal: Mapeando conceitos. Paidéia (Ribeirão Preto), 16(35), 315-325. doi:10.1590/S0103-863X2006000300003

Pergher, N. K. (2010). Variáveis que devem ser consideradas na avaliação da qualidade do relacionamento conjugal. Revista Perspectivas, 1(2), 116-129.

Pistole, M. C., \& Arricale, F. (2003). Understanding attachment: Beliefs about conflict. Journal of Counseling \& Development, 81(3), 318-328. doi:10.1002/j.1556-6678.2003.tb00259.x

Rust, J., Bennun, I., Crowe, M., \& Golombok, S. (1990). The GRIMS: A psychometric instrument for the assessment of marital discord. Journal of Family Therapy, 12(1), 45-57. doi:10.1046/j..1990.00369.x

Rust, J., Bennun, I., Crowe, M., \& Golombok, S. (2010). The Golombok Rust Inventory of Marital State (GRIMS). Sexual and Relationship Therapy, 25(1), 48-53. doi:10.1080/14681990903550183

Salvatore, J. E., Kuo, S. I.-C., Steele, R. D., Simpson, J. A., \& Collins, W. A. (2011). Recovering from conflict in romantic relationships: A developmental perspective. Psychological Science, 22(3), 376-383. doi:10.1177/0956797610397055

Scorsolini-Comin, F., \& Santos, M. A. (2009). Casar e ser feliz: Mapeando a mensuração da satisfação conjugal. Psico, 40(4), 430-437.

Segrin, C., Hanzal, A., \& Domschke, T. J. (2009). Accuracy and bias in newlywed couples' perceptions of conflict styles and the association with marital satisfaction. Communication Monographs, 76(2), 207-233. doi:10.1080/03637750902828404

Silva, G. A. (2008). Estudo longitudinal sobre prevalência e fatores de risco para depressão pós-parto em mães de baixa renda (Master's thesis, Universidade de São Paulo, São Paulo-SP, Brazil). Retrieved from http://www. teses.usp.br/teses/disponiveis/47/47132/tde-29072009162342/pt-br.php

Timm, T. M., \& Keiley, M. K. (2011). The effects of differentiation of self, adult attachment, and sexual communication on sexual and marital satisfaction: A path analysis. Journal of Sex \& Marital Therapy, 37(3), 206-223. doi:10.1080/0092623X.2011.564513

Wheeler, L. A., Updegraff, K. A., \& Thayer, S. M. (2010). Conflict resolution in Mexican-origin couples: Culture, gender, and marital quality. Journal of Marriage and Family, 72(4), 991-1005. doi:10.1111/j.1741-3737.2010.00744.x
Patricia Scheeren is a Ph.D. candidate of the Graduate Program in Psychology at the Universidade Federal do Rio Grande do Sul.

Rebeca Veras de Andrade Vieira is a Ph.D. candidate of the Graduate Program in Psychology at the Universidade Federal do Rio Grande do Sul.

Viviane Ribeiro Goulart holds a master's degree in Psychology from the Universidade Federal do Rio Grande do Sul.

Adriana Wagner is an Adjunct Professor of the Instituto de Psicologia at the Universidade Federal do Rio Grande do Sul.

Received: Sep. 27, 2013

1st Revision: Jan. 7, 2014

2nd Revision: Jan 29, 2014

Approved: Mar. 6, 2014
How to cite this article:

Scheeren, P., Vieira, R. V. A., Goulart, V. R., \& Wagner, A. (2014). Marital quality and attachment: The mediator role of conflict resolution styles. Paidéia (Ribeirão Preto), 24(58), 177-186. doi: 10.1590/1982-43272458201405 